\title{
Colorectal Neuroendocrine Tumor pTO TNM Finding v8
}

National Cancer Institute

\section{Source}

National Cancer Institute. Colorectal Neuroendocrine Tumor pTO TNM Finding v8. NCI

Thesaurus. Code C135185.

Colorectal neuroendocrine tumor with no evidence of primary tumor. (from AJCC 8th Ed.) 